\title{
Habitat Features and Their Influence on the Restoration Potential of Marine Habitats in Europe
}

Trine Bekkby ${ }^{1 *}$, Nadia Papadopoulou ${ }^{2}$, Dario Fiorentino ${ }^{3,4}$, Chris J. McOwen ${ }^{5}$, Eli Rinde ${ }^{1}$, Christoffer Boström ${ }^{6}$, Marina Carreiro-Silva ${ }^{7}$, Cristina Linares ${ }^{8}$, Guri Sogn Andersen ${ }^{1}$, Elizabeth Grace Tunka Bengil/,10, Meri Bilan ${ }^{7}$, Emma Cebrian ${ }^{11,12}$, Carlo Cerrano ${ }^{13,14}$, Roberto Danovaro ${ }^{13,14}$, Camilla With Fagerli', Simonetta Fraschetti14,15,16, Karine Gagnon ${ }^{6}$, Cristina Gambi ${ }^{13}$, Hege Gundersen ${ }^{1}$, Silvija Kipson ${ }^{17}$, Jonne Kotta ${ }^{18}$, Telmo Morato ${ }^{7}$, Henn Ojaveer ${ }^{19,20}$, Eva Ramirez-Llodra ${ }^{1,21}$ and Christopher J. Smith ${ }^{2}$

\section{OPEN ACCESS}

Edited by:

Avigdor Abelson,

Tel Aviv University, Israel

Reviewed by:

Susana Perera-Valderrama,

National Commission

for the Knowledge and Use of Biodiversity (CONABIO), Mexico

Camilla Novaglio,

CSIRO Oceans and Atmosphere

(O\&A), Australia

*Correspondence:

Trine Bekkby

trine.bekkby@niva.no

Specialty section

This article was submitted to

Marine Conservation

and Sustainability,

a section of the journal

Frontiers in Marine Science

Received: 02 September 2019

Accepted: 09 March 2020

Published: 07 April 2020

Citation:

Bekkby T, Papadopoulou N,

Fiorentino $D, M c O$ wen $C J$, Rinde $E$,

Boström C, Carreiro-Silva M,

Linares $C$, Andersen GS, Bengil EGT,

Bilan M, Cebrian E, Cerrano C,

Danovaro R, Fagerli CW, Fraschetti S,

Gagnon K, Gambi C, Gundersen H, Kipson S, Kotta J, Morato T,

Ojaveer H, Ramirez-Llodra E and

Smith CJ (2020) Habitat Features and Their Influence on the Restoration

Potential of Marine Habitats

in Europe. Front. Mar. Sci. 7:184.

doi: 10.3389/fmars.2020.00184
${ }^{1}$ Norwegian Institute for Water Research, Oslo, Norway, ${ }^{2}$ Hellenic Centre for Marine Research, Heraklion, Greece, ${ }^{3}$ Alfred Wegener Institute, Helmholtz Center for Polar and Marine Research, Bremerhaven, Germany, ${ }^{4}$ Helmholtz Institute for Functional Marine Biodiversity, University of Oldenburg, Oldenburg, Germany, ${ }^{5}$ The United Nations Environment Programme World Conservation Monitoring Centre, Cambridge, United Kingdom, ${ }^{6}$ Environmental and Marine Biology, Åbo Akademi University, Turku, Finland, ${ }^{7}$ Instituto do Mar, Marine and Environmental Sciences Centre, Centro OKEANOS, Universidade dos Açores, Horta, Portugal, ${ }^{8}$ Department of Evolutionary Biology, Ecology and Environmental Sciences, Institute for Research on Biodiversity, University of Barcelona, Barcelona, Spain, ${ }^{9}$ Mediterranean Conservation Society, izmir, Turkey, ${ }^{10}$ Marine School, Girne American University, Girne, Turkey, ${ }^{11}$ Institute of Aquatic Ecology, University of Girona, Girona, Spain, ${ }^{12}$ Centre d'Estudis Avançats de Blanes, Consejo Superior de Investigaciones Científicas (CEAB-CSIC), Blanes, Spain, ${ }^{13}$ Department of Life and Environmental Sciences, Polytechnic University of Marche, Ancona, Italy, ${ }^{14}$ Stazione Zoologica Anthon Dohrn, Naples, Italy, ${ }^{15}$ Department of Biology, University of Naples Federico II, Naples, Italy, ${ }^{16}$ Consorzio Nazionale Interuniversitario per le Scienze del Mare (CoNISMa), Rome, Italy, ${ }^{17}$ Department of Biology, Faculty of Science, University of Zagreb, Zagreb, Croatia, ${ }^{18}$ Estonian Marine Institute, University of Tartu, Tallinn, Estonia, ${ }^{19}$ Pärnu College, University of Tartu, Pärnu, Estonia, ${ }^{20}$ National Institute of Aquatic Resources, Technical University of Denmark, Lyngby, Denmark, ${ }^{21}$ REV Ocean, Lysaker, Norway

To understand the restoration potential of degraded habitats, it is important to know the key processes and habitat features that allow for recovery after disturbance. As part of the EU (Horizon 2020) funded MERCES project, a group of European experts compiled and assessed current knowledge, from both past and ongoing restoration efforts, within the Mediterranean Sea, the Baltic Sea, and the North-East Atlantic Ocean. The aim was to provide an expert judgment of how different habitat features could impact restoration success and enhance the recovery of marine habitats. A set of biological and ecological features (i.e., life-history traits, population connectivity, spatial distribution, structural complexity, and the potential for regime shifts) were identified and scored according to their contribution to the successful accomplishment of habitat restoration for five habitats: seagrass meadows, kelp forests, Cystoseira macroalgal beds, coralligenous assemblages and cold-water coral habitats. The expert group concluded that most of the kelp forests features facilitate successful restoration, while the features for the coralligenous assemblages and the cold-water coral habitat did not promote successful restoration. For the other habitats the conclusions were much more variable. The lack of knowledge on the relationship between acting pressures and resulting changes in the ecological state of habitats is a major challenge for implementing restoration actions. This paper provides an overview of essential features that can affect restoration success in marine habitats of key importance for valuable ecosystem services.

Keywords: degraded habitats, restoration success, recovery, seagrass, macroalgae, coralligenous assemblages, corals 


\section{INTRODUCTION: DEGRADATION AND RESTORATION OF HABITATS IN EUROPEAN SEAS}

For centuries humans have been reliant upon the ocean as a source of food, transport, and leisure. As resources become increasingly scarce and populations continue to grow, we are progressively turning to the coasts and oceans to drive the global economy and stimulate innovation and growth (EC, 2018). The potential for economic opportunities in the coastal region is great, resulting in convergence of different activities, such as shipping, tourism and energy production, alongside traditional resource-based activities, such as coastal fisheries, seaweed harvesting, and aquaculture. There is now ample evidence that such opportunities come with significant environmental risk and costs (e.g., Ramirez-Llodra et al., 2011; Halpern et al., 2015). Human activities exert considerable pressure on ecosystems and resources through pollution, overexploitation of resources, introduction of invasive species and habitat clearance and fragmentation (Dailianis et al., 2018; Gerovasileiou et al., 2019). Together, such activities are resulting in a decline in biodiversity, a reduction in the capacity of the oceans to provide ecosystem goods and services (Worm et al., 2006; EEA, 2015) and increased vulnerability of marine ecosystems to additional pressures such as climate change and ocean-acidification stressors (Folke et al., 2004).

In an attempt to reverse the current level of degradation within European seas, the EU Biodiversity Strategy 2020 aims to restore at least $15 \%$ of degraded ecosystems by 2020 , in accordance with the 2010 Aichi targets and the UN 2030 Agenda for Sustainable Development ${ }^{1}$. However, whilst marine restoration actions are common in many areas of the world, their success rate is highly variable. For instance, whilst $65 \%$ of tropical coral reef and salt marsh restoration projects successfully achieved their goals, seagrass restoration has had a success rate of only $38 \%$ (Bayraktarov et al., 2016; van Katwijk et al., 2016). Variation in restoration success stems from different sources, including the inherent biology and ecology of species, including their interactions (Kilminster et al., 2015) and how, where and when restoration is conducted (Montero-Serra et al., 2018a). This variation leads to uncertainty in terms of conservation outcomes and economics. Consequently, there is a need to develop robust methodologies to effectively restore habitats and deliver the full range of conservation and socioeconomic benefits that can be derived (Elliott et al., 2007).

Historically, research on restoration best practices and methods has mainly focused on terrestrial, rather than on marine, ecosystems. Even though several of the basic principles developed in terrestrial systems can be used in the marine realm (van Dover et al., 2014; Da Ros et al., 2019), the knowledge on which factors are enhancing or limiting restoration success is very limited for the marine environment. The H2020 MERCES project ${ }^{2}$ aims to enhance the European Union's capacity to restore degraded marine ecosystems and habitats and the ecosystem services they

${ }^{1}$ https://undocs.org/A/RES/70/1

${ }^{2}$ www.merces-project.eu provide. As part of this effort, the present paper seeks to structure and discuss the existing knowledge amongst leading European experts on the restoration potential of some important marine habitats within Europe. The discussion includes the biological and ecological features that determine the habitats' sensitivity to human pressures and thereby modulate the success of restoration actions. This information will provide the basis for knowledgebased guidelines of how to advance marine ecosystem restoration and increase the political and management willingness to initiate restoration actions.

\section{THE APPROACH}

A total of 25 experts representing 11 European countries, from Norway and Finland in the north to Crete in Greece in the south, was part of a MERCES initiated workshop to discuss habitat restoration activities. The group had expertise on species biology and ecology, covering key habitats found within the Mediterranean Sea, the Baltic Sea, and the NE Atlantic Ocean. A set of focal habitats were selected (section Selection and Description of the Target Habitats), and the experts were asked to suggest and agree on a set of key biological and ecological features (section Selection of Habitat Features and Assessment ("Scoring") of the Restoration Potential) that were important to the recovery of these habitats. Following this discussion, each feature was discussed in terms of their relevance to the recovery potential, in general and for each habitat separately. The agreed-on features and characteristics were based on knowledge from both past and ongoing restoration efforts, within the European seas. The aim was to provide a consensual judgment (a "scoring," section Selection of Habitat Features and Assessment ("Scoring") of the Restoration Potential) on how different biological and ecological features impact restoration success and the recovery of habitats.

Throughout this paper, the term "restoration" refers to an intentional activity (i.e., active intervention or manipulation) that initiates or accelerates the recovery of an ecosystem with respect to its health, integrity, and sustainability (SER, 2004). Active approaches, also referred to as assisted regeneration $(\mathrm{McD}$ onald et al., 2016), include seedling of spores, transplantation, the removal of grazers, etc. The recovery of the ecosystem is defined as the reinstatement of ecosystem attributes, such as composition, structure, and function, back to a level identified for a reference ecosystem (McDonald et al., 2016). We do not include passive restoration (natural re-generation), where restoration goals are achieved by allowing the ecosystem to recover once the source of disturbance has been removed.

\section{Selection and Description of the Target Habitats}

The five marine habitats chosen for this paper were selected by the expert group at the workshop because they are considered to be highly ecological and economic important, are sensitive to human activities and are relevant in conservation. Different directives and list were used as guidance when making the agreed-on list of target habitats: EU Habitats Directive 92/43/EEC, OSPAR List of Threatened and/or Declining Species 
and Habitats (OSPAR, 2008), HELCOM List of Threatened and/or Declining Species and biotopes/habitats in the Baltic Sea (HELCOM, 2007), UNEP/MAP-SPA/RAC 2018 Annex II List of Endangered or threatened species. The selected habitats cover shallow and deep areas and soft and hard substrates in the Mediterranean Sea, the Baltic Sea and NE Atlantic Ocean (see Figure 1 for habitat examples).

Seagrass meadows are found on soft bottoms down to a maximum depth of $50 \mathrm{~m}$ (Duarte, 1991b). Seagrasses are important ecosystem engineers, i.e., they create, modify and maintain habitats (Boström et al., 2014; Jahnke et al., 2016), and provide multiple ecosystem services through stabilizing sediments, sequestering carbon, filtering nutrients and providing food and shelter for invertebrates, fish and birds (Hemminga and Duarte, 2000). Different human pressures are responsible for the decline of seagrasses in Europe (Airoldi and Beck, 2007). Whilst seagrass loss has been accelerating through decades (Waycott et al., 2009), recent assessment demonstrates a more positive trend in Europe (de los Santos et al., 2019).

Kelp forests are found on rocky seabed down to a depth of about $30 \mathrm{~m}$, with single individuals (i.e., not forests) growing even deeper. Kelps are habitat-forming species, providing food, shelter and habitat for many species (Christie et al., 2009; Leclerc et al., 2013). They play a major role in the carbon cycle (KrauseJensen and Duarte, 2016) and coastal protection, along with a
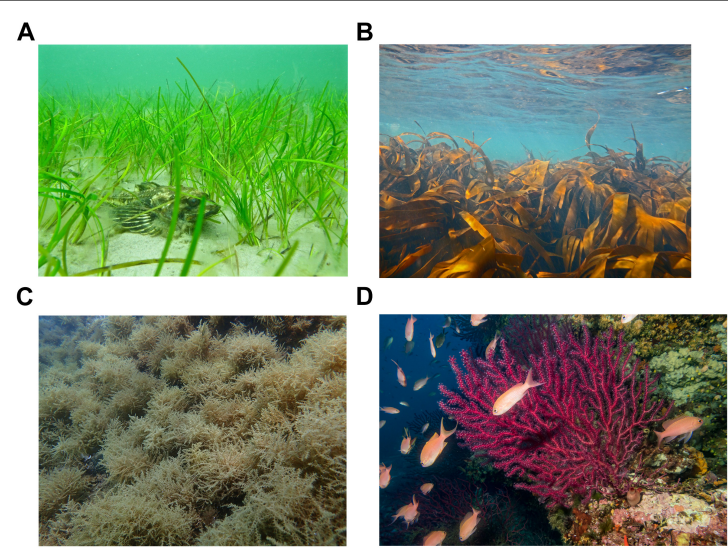

E

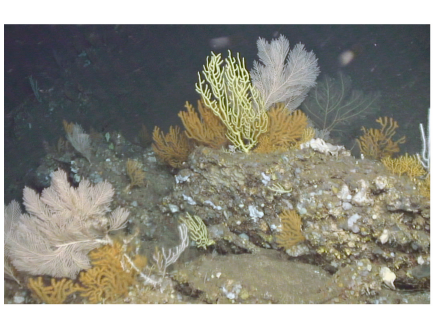

FIGURE 1 | Examples of the selected marine habitats assessed in this paper: (A) Zostera marina seagrass meadow, (B) Laminaria hyperborea kelp forest, (C) Treptacantha elegans macroalgal bed, (D) Mediterranean coralligenous assemblage, and (E) Cold-water coral habitat, dominated by the octocorals Callogorgia verticillata, Acanthogorgia sp. and Dentomuricea aff. meteor in the Azores. Photos by Christoffer Boström (A), Janne K. Gitmark (B), Alba Medrano (C), Cristina Linares (D) and EMEPC, ROV Luso (EMEPC/Luso/Açores/2009) (E). long list of other ecosystem services (Gundersen et al., 2016). The kelp forest distribution is decreasing in many areas around the world (Filbee-Dexter and Wernberg, 2018) but is also showing increasing trends in some parts (e.g., recovering in the Norwegian NE Atlantic, Araújo et al., 2016; Krumhansl et al., 2016).

Cystoseira macroalgal beds are found down to a maximum depth of $50 \mathrm{~m}$. Cystoseira spp. are habitat-forming species found in rocky intertidal and subtidal coastal areas and are recognized as hot spots for biodiversity. They provide food and habitat to diverse assemblages of understory species and enhance coastal primary productivity (Ballesteros, 1990; Ballesteros et al., 1998; Cheminée et al., 2013). Shallow beds (mainly down to $10 \mathrm{~m}$ depth) have a different community composition and different life history traits than deeper ones (10-50 m depth, Capdevila et al., 2016). The decline in Cystoseira over vast areas has been documented in many regions (Bianchi et al., 2014; Thibaut et al., 2015) and natural recovery has been recorded only occasionally (Perkol-Finkel and Airoldi, 2010; Iveša et al., 2016).

Coralligenous assemblages can be found down to maximum depth of about $120 \mathrm{~m}$ (Laborel, 1961). Coralligenous outcrops are mainly produced by the accumulation of calcareous encrusting algae. This habitat supports high biodiversity (approximately 10$20 \%$ of the Mediterranean species) and structural complexity (Ballesteros, 2006), and the most abundant species are long-lived algae and sessile invertebrates with an important role as habitatformers (Linares et al., 2007; Cerrano et al., 2010; Teixidó et al., 2011). Coralligenous assemblages have been lost or degraded in several areas across the Mediterranean Sea (Bevilacqua et al., 2018; Ingrosso et al., 2018).

Cold-water coral habitats are major ecosystem engineers in the deep sea, mostly occurring in the depth range of 200$1500 \mathrm{~m}$, where they can form large and extensive habitats, such as coral reefs formed mostly by Scleractinia species (stony corals) and coral gardens primarily composed by octocorals and black corals (Roberts et al., 2009; Buhl-Mortensen and BuhlMortensen, 2018). They create a complex three-dimensional habitat and support high levels of biodiversity, providing refuge, feeding opportunities, and spawning and nursery areas for a wide range of organisms (Buhl-Mortensen et al., 2010). Cold-water corals grow extremely slowly (a few to several mm per year) and can live for hundreds or thousands of years (e.g., Roberts et al., 2009; Watling et al., 2011; Carreiro-Silva et al., 2013). The limited knowledge on the distribution and extent of cold-water coral habitats makes it difficult to assess changes. Nevertheless, cold-water coral habitats have been defined as Vulnerable Marine Ecosystems (VMEs, FAO, 2009) and international management and conservation policies (e.g., FAO, OSPAR) are expected to contribute to the recovery of impacted sites and the protection of the remaining pristine coral communities.

\section{Selection of Habitat Features and Assessment ("Scoring") of the Restoration Potential}

The recovery potential of habitats depends upon their resilience, which is strongly influenced by the biology and ecology of their component species. The expert group identified and agreed 
on the biological and ecological features of greatest relevance through discussion and by structuring information from literature reviews (Perkol-Finkel and Airoldi, 2010; Abelson et al., 2016a,b; McDonald et al., 2016). This resulted in the selection of five features most relevant to restoration success, namely: life-history traits, population connectivity, spatial distribution, structural complexity, and the potential for regime shifts. The features' general relevance to the recovery potential of habitats is described in Table $\mathbf{1}$.

By using the features, the expert group assessed the restoration potential of the selected habitats based on (1) evidence in the published literature, (2) experiences obtained from ongoing restoration projects and actions, and (3) expert knowledge of the habitats' or species' biology and ecology. The discussion ended up with agreed-on characteristics of the biological and ecological features for each habitat (Table 2). Based on these characteristics, each feature was given a score from 1 (low) to 5 (high), according to its potential contribution to the successful accomplishment of restoration for each of the habitats (Table 3 ). We chose five levels to ensure that enough variability could be included in the assessment to distinguish restoration potential amongst habitats, but that did not have too many levels that would hide emerging patterns. This number of levels have also been considered suitable for defining conservation status of habitats and species (from favorable to unknown under the EU Habitats Directive) and ecosystem health status of marine waters (from high to bad under the Water Framework Directive). When a feature may lead to both restoration failure and success, the scoring was given as a range or a set of values, rather than one single score. As shallow Cystoseira beds have a different community and different life history traits than deeper beds, these communities were scored separately.

\section{THE ASSESSMENT OF THE HABITAT FEATURES AND THE RESULTING "SCORING"}

The characteristics of the biological and ecological features relevant for assessing the recovery potential is described in sections Seagrass meadows to Cold-Water Coral Habitats and summed up in Table 2. Table 2 provides the information needed for the agreed-on scoring in Table 3 , in which the features of the different habitats are considered according to their contribution to successful restoration.

\section{Seagrass Meadows}

As life-history traits of seagrass may lead to restoration failure or success, depending on the species in question, it is difficult to assess this feature's importance for habitat restoration in general (Kilminster et al., 2015). For example, Posidonia oceanica is a slow-growing species (Duarte, 1991a) forming enduring meadows (Kilminster et al., 2015), while Cymodocea nodosa and Zostera marina exhibit faster clonal growth (Olesen and SandJensen, 1993; Cancemi et al., 2002), forming more transient meadows (Kilminster et al., 2015). As slow-growing species will need more time to recover than fast-growing species
(Montero-Serra et al., 2018a), the time scale needed for recovery should be assessed carefully depending on the species in question. In general, populations with high connectivity (dispersal and gene flow) have higher genetic diversity, which makes them more resilient to environmental perturbations (Reusch et al., 2005; Jahnke et al., 2018). However, especially at the extreme ends of the geographical range of eelgrass, clonal growth dominates, creating vulnerable and isolated populations with limited connectivity (Olsen et al., 2004). Several species may spread both asexual (clonal) and through seed production (McMahon et al., 2014). Thus, different geographical regions and species naturally possess different capacities for local and large-scale dispersal (gene flow), from less than $15 \mathrm{~m}$ to up to $1000 \mathrm{~km}$ (Orth et al., 1994; Källström et al., 2008; Jahnke et al., 2018). The distribution of the species is also crucial, as a wide spatial distribution implies easier access to donor populations during restoration, which increases the probability of recovery success. In general, largescale planting has been identified as an important method for increasing restoration success (van Katwijk et al., 2016).

Seagrass meadows are extremely vulnerable to anthropogenic pressures, such as habitat destruction, eutrophication, pollution, and climate change (Orth et al., 2006). It is important that pressures, such as eutrophication (which limits light availability and growth, Burkholder et al., 2007; Moksnes et al., 2018) and habitat destruction (Erftemeijer and Lewis, 2006), are removed and appropriate sediment conditions are re-established, as sediment conditions tend to become unsuitable for reestablishment following seagrass loss (de Boer, 2007; Carr et al., 2016; Moksnes et al., 2018). Seagrass meadows are prone to regime shifts (Maxwell et al., 2016; Moksnes et al., 2018), characterized by a transition into an algal dominated or a barren state. Understanding drivers, interactions and thresholds in these regime shifts is crucial before any restoration action can take place.

After restoration action has taken place, seagrass meadows should be sustained in the long-term through positive feedback mechanisms (Maxwell et al., 2016; Suykerbuyk et al., 2016). As part of restoration it is therefore important to ensure (and possibility reintroduce) healthy populations of associated species, especially top predators, which can control algal (over)growth through trophic cascades (Moksnes et al., 2008, 2018; Jahnke et al., 2018).

\section{Kelp Forests}

All of the selected features associated with kelp forests promote successful restoration. Fertile kelp produces a high number of propagules that can be dispersed for several days with coastal currents (Reed et al., 1992; Andersen, 2013), and the release is relatively synchronous among populations (Andersen et al., 2011). Connectivity between kelp populations is reinforced by reproductive synchrony because higher abundance of spores in the currents increases the probability of long-distance dispersal (Reed et al., 1997), which also facilitates recovery. Kelp colonizes hard substrate such as bedrock, boulders, and rocks, forming forests with a wide spatial distribution. Kelp forests are structurally very complex, with a heterogeneous understory of younger plants and associated flora and fauna. Kelp forests 
TABLE 1 | Description of the key features assessed for the habitats included in this paper and their relevance to the recovery potential.

\begin{tabular}{|c|c|c|c|}
\hline Key features & Description & Relevance to the recovery potential & References \\
\hline Life history traits & $\begin{array}{l}\text { Reproduction potential, } \\
\text { larval biology, age at first } \\
\text { maturity, growth rate, } \\
\text { longevity, generation length. }\end{array}$ & $\begin{array}{l}\text { Species with low reproductive output, delayed } \\
\text { maturity, slow growth, and high longevity take } \\
\text { longer to recover from impact. }\end{array}$ & $\begin{array}{l}\text { McMahon et al., 2014; Capdevila } \\
\text { et al., 2016; Montero-Serra et al., } \\
2018 \text { a }\end{array}$ \\
\hline Population connectivity & Dispersal and gene flow. & $\begin{array}{l}\text { Populations with high connectivity/gene flow } \\
\text { have higher genetic diversity, which provides } \\
\text { resistance to disturbance and high potential for } \\
\text { natural recolonization of disturbed areas from } \\
\text { nearby sites. }\end{array}$ & $\begin{array}{l}\text { Pascual et al., 2017; Jahnke et al., } \\
2018\end{array}$ \\
\hline Spatial distribution & $\begin{array}{l}\text { Spatial extent, distribution } \\
\text { patterns. }\end{array}$ & $\begin{array}{l}\text { Populations in fragmented habitats are more } \\
\text { vulnerable to environmental impact and genetic } \\
\text { stochasticity, and therefore face a higher risk of } \\
\text { local extinction. }\end{array}$ & $\begin{array}{l}\text { Gera et al., 2013; Giakoumi et al., } \\
2013\end{array}$ \\
\hline Structural complexity & $\begin{array}{l}\text { Three-dimensional } \\
\text { complexity. }\end{array}$ & $\begin{array}{l}\text { Increased habitat complexity supports higher } \\
\text { biodiversity and thus associated food webs, } \\
\text { thereby enhancing recovery through various } \\
\text { ecosystem processes, including facilitation, and } \\
\text { positive feedbacks between coexisting species. }\end{array}$ & Kovalenko et al., 2012 \\
\hline Regime shift & $\begin{array}{l}\text { The potential for regime } \\
\text { shift. }\end{array}$ & $\begin{array}{l}\text { Habitats that experience variation in extent, } \\
\text { coverage and status, but that don't experience } \\
\text { regime shifts, will recover more easily than } \\
\text { habitats that show regime shifts }\end{array}$ & $\begin{array}{l}\text { Hughes et al., 2013; Maxwell et al., } \\
2016\end{array}$ \\
\hline
\end{tabular}

generally support food webs with a high number of species at different trophic levels (e.g., Steneck et al., 2002; Smale et al., 2013; Krause-Jensen and Duarte, 2014) contributing to ecosystem resilience.

Restoration actions may be implemented at large spatial scales and transplanted or recovered kelp plants can quickly become spore donors to adjacent barren areas. The major threats for kelp (reviewed in Filbee-Dexter and Wernberg, 2018) are eutrophication, temperature increase (in the North Sea, Bekkby and Moy, 2011; Moy and Christie, 2012) and grazing by sea urchins (in the Norwegian and Barents Sea, Araújo et al., 2016), but kelp forests show high level of recovery when these pressures are removed. Consequently, removing pressures, such as sea urchins and nutrients, should be the priority before any additional actions (such as planting kelp or seeding spores). Despite the documented regime shift and widespread collapse of kelp forests (Ling et al., 2015), such as for the Laminaria hyperborea forests, some forests have had a back-and-forth shift between kelp and turf algae, without it being a regime shift (e.g., Saccharina latissima, Christie et al., 2019). Before any restoration action can take place, an in-depth understanding of the drivers, feedback effects and critical thresholds for the shifts is needed, including knowledge of the interaction with predators (such as sea urchins), turf algae and local and global stressors.

\section{Cystoseira Macroalgal Beds}

Cystoseira macroalgal beds display relatively high reproduction, growth rate and longevity (Ballesteros, 1989), with a considerable variation in life history traits at different depths (Capdevila et al., 2016). The shallow beds have, in general (but with exceptions), wide spatial distribution and are dominant habitatforming species in rocky intertidal and subtidal habitats, while deeper beds are more fragmented. Cystoseira beds have a high structural complexity, providing food and shelter to diversified assemblages of understory species. Cystoseira beds are vulnerable to various anthropogenic pressures (such as eutrophication, chemical pollution, coastal development, sedimentation) as well as being at risk due to climate change and outbreaks of grazers (Fraschetti et al., 2001; Airoldi et al., 2014). Overgrazing due to sea urchin outbreaks is responsible, along with other local and global stressors, for the loss of Cystoseira beds and the subsequent community shifts toward turf-forming algae or barren grounds (Pinnegar et al., 2000; Airoldi et al., 2014).

The high level of fragmentation often found for this habitat and the low connectivity (Thibaut et al., 2016) suggest that restoration actions should be considered over a local scale (meters). Restoration should focus on structural species that provide habitat for associated species. Shallow beds have high growth and fast dynamics (Ballesteros, 1989) and may be easier to restore compared to deeper beds (e.g., below $30 \mathrm{~m}$ depth). Restoration actions should include large adult organisms. However, in cases where the natural and donor populations are in a critical state, manipulation should be avoided, and restoration must rely on recruitment enhancement and the growth of juveniles (Verdura et al., 2018; De La Fuente et al., 2019). In these situations, a longer time (possible decades) for restoration must be accepted (Mangialajo et al., 2012; Capdevila et al., 2016; Thibaut et al., 2016). Anthropogenic pressures (such as eutrophication, chemical pollution, coastal development, sedimentation) should be reduced. Restoration practitioners have found that a combination of two approaches (sea urchin eradication to control their impact, and recruitment enhancement techniques) was the best technique to enhance Cystoseira forestation from a shallow degraded barren ground (Medrano et al. unpublished data). 
TABLE 2 | The characteristics of the five selected key features for each habitat.

\begin{tabular}{|c|c|c|c|c|c|c|}
\hline \multirow[t]{2}{*}{ Habitat } & & \multicolumn{5}{|c|}{ Habitat features } \\
\hline & & Life history & $\begin{array}{l}\text { Population } \\
\text { connectivity }\end{array}$ & Spatial distribution & Structural complexity & Regime shifts \\
\hline Seagrass meadows & & $\begin{array}{l}\text { Both slow and } \\
\text { fast-growing species, } \\
\text { both low and high } \\
\text { reproductive output }\end{array}$ & $\begin{array}{l}\text { Generally high dispersal } \\
\text { and high gene flow, but } \\
\text { some populations are } \\
\text { clones }\end{array}$ & $\begin{array}{l}\text { Relatively fragmented } \\
\text { populations, depending } \\
\text { on the species }\end{array}$ & High 3D complexity & Prone to regime shifts \\
\hline Kelp forests & & $\begin{array}{l}\text { High recruitment, } \\
\text { growth rate and } \\
\text { longevity }\end{array}$ & $\begin{array}{l}\text { High connectivity, } \\
\text { number of propagules } \\
\text { and dispersal distance }\end{array}$ & Wide distribution & High 3D complexity & Prone to regime shifts \\
\hline \multirow[t]{2}{*}{$\begin{array}{l}\text { Cystoseira macroalgal } \\
\text { peds }\end{array}$} & (Shallow, i.e., at 0-10 m) & $\begin{array}{l}\text { Fast or medium growth } \\
\text { and recruitment rate }\end{array}$ & $\begin{array}{l}\text { Medium or poor } \\
\text { dispersal ability }\end{array}$ & $\begin{array}{l}\text { Wide distribution, but } \\
\text { might occur in patches }\end{array}$ & High 3D complexity & Prone to regime shifts \\
\hline & (Deeper, i.e., at 10-50 m) & $\begin{array}{l}\text { Slow growth and } \\
\text { recruitment rate }\end{array}$ & Poor dispersal ability & Fragmented & High 3D complexity & Prone to regime shifts \\
\hline $\begin{array}{l}\text { Coralligenous } \\
\text { assemblages }\end{array}$ & & $\begin{array}{l}\text { Slow growth and low } \\
\text { recruitment rate, long } \\
\text { life span }\end{array}$ & $\begin{array}{l}\text { Low connectivity, } \\
\text { disconnected } \\
\text { populations and limited } \\
\text { larval transport }\end{array}$ & Fragmented & High 3D complexity & Likely, but unclear \\
\hline $\begin{array}{l}\text { Cold-water coral } \\
\text { habitats }\end{array}$ & & $\begin{array}{l}\text { Slow growing, long life } \\
\text { spans, low reproductive } \\
\text { output and low } \\
\text { recruitment rate }\end{array}$ & $\begin{array}{l}\text { Low fecundity and } \\
\text { larval dispersal for most } \\
\text { species }\end{array}$ & Fragmented & High 3D complexity & Unclear \\
\hline
\end{tabular}

Shallow Cystoseira macroalgal beds have a different community and different life history traits than deeper ones and are thus treated separately. 
TABLE 3 | The agreed-on expert scoring of the habitat features according to their contribution to the successful accomplishment of habitat restoration; 1 - low contribution, 5 - high contribution.

\begin{tabular}{|c|c|c|c|c|c|c|}
\hline \multirow[t]{2}{*}{ Habitat } & & \multicolumn{5}{|c|}{ Habitat features } \\
\hline & & Life history & Population connectivity & Spatial distribution & Structural complexity & Regime shifts \\
\hline $\begin{array}{l}\text { Seagrass } \\
\text { meadows }\end{array}$ & & $1-5$ & $5(1)$ & 2 & 5 & Prone to regime shifts \\
\hline Kelp forests & & 5 & 5 & 5 & 5 & Prone to regime shifts \\
\hline $\begin{array}{l}\text { Cystoseira } \\
\text { macroalgal }\end{array}$ & (Shallow, i.e., 0-10 m) & 4 & 3 & 4 & 5 & Prone to regime shifts \\
\hline beds & (Deeper, i.e., 10-50 m) & 3 & 2 & 2 & 5 & Prone to regime shifts \\
\hline $\begin{array}{l}\text { Coralligenous } \\
\text { assemblages }\end{array}$ & & 2 & 1 & 1 & 5 & Likely, but unclear \\
\hline $\begin{array}{l}\text { Cold-water } \\
\text { coral habitats }\end{array}$ & & 1 & 1 & 1 & 5 & Unclear \\
\hline
\end{tabular}

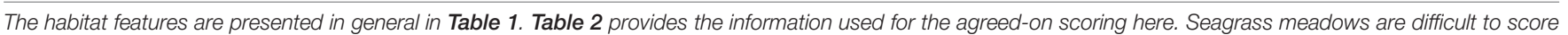

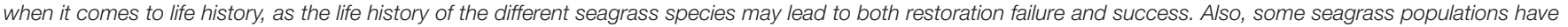

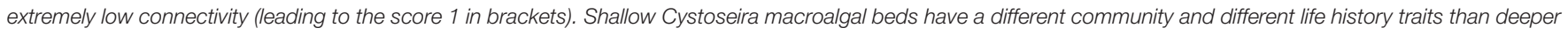
beds, and scores are therefore given separately.

\section{Coralligenous Assemblages}

Coralligenous assemblages form through the growth of organisms on dead skeletons of previous generations, creating high structural complexity. Most are calcareous algae, sponges, bryozoans, and octocorals, which are relatively slow-growing and long-lived species, with limited recruitment (Coma et al., 1998; Garrabou and Harmelin, 2002; Linares et al., 2007; Teixidó et al., 2011). In addition, populations of different coralligenous species, such as the octocorals Paramuricea clavata and Corallium rubrum, are most likely far apart, and larval supply may be limited (Costantini et al., 2007; Ledoux et al., 2010; Arizmendi-Meija et al., 2015).

Restoration through transplantation would require low initial effort due to high survival of transplants. As coralligenous species are slow-growing and long-lived, with limited recruitment, it takes a long period of time to restore the full complexity of the habitat through transplantation, probably at decadal timescales (Linares et al., 2008; Montero-Serra et al., 2018a). This would be the case for most of the key coralligenous groups, such as sponges (e.g., Petrosia fisciformis, Spongia lamella, S. officinalis) and octocorals (e.g., Paramuricea clavata, Corallium rubrum) (Teixidó et al., 2011; Montero-Serra et al., 2018b). However, there are other groups, such as bryozoans, mainly Pentapora fascialis, which can display higher growth rates, and recovery of structural complexity could be achieved in short time scales (5-10 years, Pagés et al. unpublished data). As the habitats are generally fragmented and the population connectivity low, restoration actions need to be performed at very local scales.

Coralligenous assemblages are presently threatened by a combination of nutrient enrichment, invasive species, increase of sedimentation and mechanical impacts, mainly from fishing activities, as well as climate change (Ballesteros, 2006; Balata et al., 2007; Garrabou et al., 2009; Cebrian et al., 2012; Piazzi et al., 2012). Reduction of pressures should be a priority before starting restoration actions. The slow population dynamics of coralligenous assemblages make it difficult to detect regime shifts, which could be eventually detected after longer time periods exposed to stressors. However, experimental and observational evidences show that extreme warming events can replace a structurally complex habitat with fast-growing and turf-forming species, which can indicate regime shifts (Ponti et al., 2014; Di Camillo and Cerrano, 2015; Verdura et al., 2019).

\section{Cold-Water Coral Habitats}

Cold-water coral habitats have among the lowest recovery potentials. This is related to coral life-history traits such as slow growth, high longevity and low fecundity, which makes their recovery dynamics extremely slow, particularly for octocorals and black corals. Bypassing sensitive early-life stages, by transplanting adult and reproductive colonies of key coral species, may accelerate the initial recovery of the ecosystem (e.g., Linares et al., 2008; Montero-Serra et al., 2018a). However, the life-history traits of the species will condition the slow recovery of the ecosystem, including its full biodiversity, structure and functioning, which will likely require several decades to centuries. This is because individual native species will regenerate naturally at different time scales and because transplantation may be feasible only for a limited number of species (and if donors are available). Therefore, the appropriate choice of species to transplant may be important, giving priority to species with relatively fast growth rates, so that they can more easily recover and create the threedimensional structure needed for associated species. The slow population dynamics of the cold-water coral habitats makes it difficult to really know if they are prone to regime shifts, as it would take long-lasting studies.

Cold-water coral habitats are sensitive to a range of human activities, including commercial bottom fisheries, hydrocarbon exploration and extraction, and if developed, deep-sea mining (Ramirez-Llodra et al., 2011; Ragnarsson et al., 2017). The bottom fisheries are considered to be the major pressure, often resulting in the removal of entire communities, with little evidence of recovery (Clark et al., 2019). An important challenge in the restoration of deep-sea coral habitats is the remoteness of these habitats, which makes restoration actions highly dependent on 
technological means (e.g., large ships and ROVs), being costly in comparison with shallow-water habitats (van Dover et al., 2014; Da Ros et al., 2019). This may reduce the capacity to restore large areas using coral transplants. Thus, a combination of restoration approaches will likely be necessary, with assisted regeneration at small scales and natural regeneration (through fisheries closures, marine protected areas) at large scales.

\section{CONCLUSION AND FUTURE PERSPECTIVES ON RESTORATION}

Active restoration is required where the impact of human pressures goes beyond a point where no passive (unassisted) recovery may take place or does not proceed at the desired speed. Undertaking active restoration may provide conservation outcomes (Possingham et al., 2015) and should be used in combination with other management practices, such as protected areas (Barbier et al., 2014; van Dover et al., 2014; Da Ros et al., 2019).

Based on the discussions and scoring of the biological and ecological features and their contribution to the successful accomplishment of habitat restoration, the expert group concluded that most of the kelp forest features facilitate successful restoration (high score in Table 3), while the features for the coralligenous assemblages and the cold-water coral habitat did not promote successful restoration (low score). For seagrass meadows and Cystoseira macroalgal beds the conclusions were much more variable. Life-history traits of seagrass may lead to restoration failure or success, depending on the species (Table 2), which makes it difficult to score this feature according to its contribution of the successful accomplishment of habitat restoration.

The success of restoration actions depends upon the inherent ecology and biology of the species and habitats being restored. Life history and population connectivity impact restoration success, while structural complexity typically is a feature that will affect the habitat's vulnerability against perturbations (see Table 2). This means that restoration actions should mainly undertake two different activities. The first step should be to protect and maintain structural complexity and diversity, the second should be devoted to enhancing the conditions crucial for those features that make the success uncertain (i.e., life history and population connectivity). The protection and maintenance of structural complexity and diversity may be achieved by coupling the restoration action with management measures to significantly reduce stressors at the restoration site (van Dover et al., 2014). Close proximity of the restoration site to more pristine habitats improves restoration potential as the unaffected populations can provide offspring to support re-colonization and population connectivity, increasing genotypic diversity, if no other limiting factors (e.g., current directions, topographic barriers) are present.

Based on the experiences from ongoing restoration projects and actions, the expert group suggests that four factors should be considered to obtain the greatest chances of success for restoration:
(1) The choice of the donor and recipient sites - to ensure that the restoration site has suitable physical conditions and biological characteristics, as similar as possible to that of the donor site.

(2) The identification of the best transplantation methodology - a multitude of transplantation techniques exists for different species and habitats. The choice of the right technique (or combination of techniques) requires reviewing existing literature and outcomes of previous restoration projects.

(3) The influence of positive species interactions - the presence of species could improve survival by for instance providing habitat or refuge, which may speed up the recovery. Instead of only minimizing competition and predation, restoration actions should also focus on positive, including co-restoration of several habitats.

(4) The potential for regime shifts - if the habitat is prone to regime shifts, in-depth understanding of the drivers, feedback effects and critical thresholds for the shifts, including the interaction between species (positive and negative) and local and global stressors, is needed.

Point 3 in the list above, which is also relevant for point 4, needs some elaboration. Even though positive interactions between species are highly recognized in ecology, it is not commonly integrated in conservation or restoration efforts. Often, the negative interactions (competition and predations) are easier to identify and is therefore more often included as part of the restoration effort (Silliman et al., 2015). Considering positive interactions are more common in terrestrial (and to a certain degree freshwater) restoration projects. However, Halpern et al. (2007) provide some guidelines on why and when positive interactions should be considered, including for marine habitats. In general, physically or biologically stressful systems benefit more from positive interactions than mild habitats (Halpern et al., 2007; Silliman et al., 2015). It is therefore important that the degree of stress in the system is assessed as part of planning the restoration action. Silliman et al. (2015) shows that doing small adjustments in the restoration design to enhance positive interactions increases the restoration success.

Often, the challenge of marine restoration is that it can require long timescales (from several years to decades) before the success of the restoration methods can be evaluated, and it requires substantial funding and high-technology equipment, particularly in deep-sea habitats (Bayraktarov et al., 2016; Verdura et al., 2018). The cost of restoration is a crucial issue, both in terms of its estimation, for example through the transparent reporting of costs, and also the efficiency of actions (Bayraktarov et al., 2016). Efficiency can be increased by structuring restoration action across several partners (Bodin and Crona, 2009) and by thinking creatively, for example using deep-sea corals from fisherman's by-catch in transplantations. In addition, for habitats such as cold-water corals, which recover slowly, short-term monitoring (i.e., a few years) cannot be expected to be a good indication of restoration trajectory or success. In these cases, management measures should be taken to ensure the long-term monitoring of the area under 
restoration, which may be beyond the typical lifetime of a restoration project. Often (as experienced in kelp forest restoration), maintaining long-term restoration actions is also a prerequisite for success (e.g., continuous sea urchin and turf algae removal).

An additional challenge in marine restoration is that in many cases (at least for the deep sea) we have limited knowledge on key features that support restoration success or can promote resilience. The lack of knowledge of pre-disturbance baselines, which may have shifted along with climate change (Pauly, 1995), is also a challenge. Ultimately, this hampers a proper evaluation of the impact of anthropogenic activities, the actual degree of degradation and therefore the choice of the restoration goals.

In conclusion, this work provides an overview of the essential biological and ecological features for a range of marine habitats (ecosystem engineers) that can affect restoration success, highlighting the key factors for a successful restoration. Moreover, we provide some best practice guidelines to improve restoration success. Even though habitat restoration is much more complicated than that which has been discussed here, it is hoped that our discussions and recommendations will be useful when designing and executing future marine restoration.

\section{AUTHOR CONTRIBUTIONS}

As part of the MERCES WP1 work, an expert group selected the marine habitats and features to be included in this manuscript. TB, NP, and CS lead the focus workshop of experts. TB, CG, CL, NP, CS, TM, DF, KG, SF, CM, EB, and EC were all part of this process and earlier analyses. At a later stage, more people were added to the expert group in order to ensure expertise on all habitats and regions, and to support the new analyses. $\mathrm{ER}, \mathrm{GA}, \mathrm{CF}$, and HG were included in the work on the kelp forests, $\mathrm{CB}$ on seagrass meadows, MC-S, TM, and MB on coldwater coral habitats, $\mathrm{CC}$ and SK on the coralligenous assemblages, $\mathrm{RD}$ and ER-L on deep-sea habitats, and JK and $\mathrm{HO}$ on habitat ecology in general. TB, NP, DF, CM, ER, CB, MC-S, and CL were

\section{REFERENCES}

Abelson, A., Halpern, B. S., Reed, D. C., Orth, R. J., Kendrick, G. A., Beck, M. W., et al. (2016a). Upgrading marine ecosystem restoration using ecological-social concepts. Bioscience 66, 156-163. doi: 10.1093/biosci/biv171

Abelson, A., Nelson, P. A., Edgar, G. J., Shashar, N., Reed, D. C., Belmaker, J., et al. (2016b). Expanding marine protected areas to include degraded coral reefs. Conserv. Biol. 30, 1182-1191. doi: 10.1111/cobi.12722

Airoldi, L., and Beck, M. W. (2007). Loss, status and trends for coastal marine habitats of Europe. Oceanogr. Mar. Biol. Annu. Rev. 45, 345-405. doi: 10.1201/ 9781420050943.ch7

Airoldi, L., Ballesteros, E., Buonuomo, R., van Belzen, J., Bouma, T. J., Cebrian, E., et al. (2014). "Marine forests at risk: solutions to halt the loss and promote the recovery of Mediterranean canopy-forming seaweeds," in The Proceedings of the 5th Mediterranean Symposium on Marine Vegetation, Portoroz, 28-33.

Andersen, G. S. (2013). Patterns of Saccharina latissima recruitment. PLoS One 8:e81092. doi: 10.1371/journal.pone.0081092

Andersen, G. S., Steen, H., Christie, H., Fredriksen, S., and Moy, F. E. (2011). Seasonal patterns of sporophyte growth, fertility, fouling, and mortality of responsible for the Table 3 "scoring," but all authors listed have contributed to the discussions and conclusions, and in writing of the manuscript.

\section{FUNDING}

This work has been part of the MERCES project (www. merces-project.eu/, Marine Ecosystem Restoration in Changing European Seas) and based on the MERCES deliverable D1.1 "State of the knowledge on European marine habitat mapping and degraded habitats". The project has received funding from the European Union's Horizon 2020 Research and Innovation Programme under the grant agreement no. 689518.

\section{ACKNOWLEDGMENTS}

We would like to thank James Aronson (Center for Conservation and Sustainable Development, CCSD, Missouri Botanical Garden), Tatjana Bakran-Petricioli (University of Zagreb), David Billett (Deep Seas Environmental Solutions Ltd.), Thanos Dailianis (Hellenic Centre for Marine Research, HCMR), Maria del Mar Otero (IUCN-Centre for Mediterranean Cooperation), Joaquim Garrabou (Institute of Marine Sciences, ICM-CSIC, Barcelona), Vasilis Gerovasileiou (Hellenic Centre for Marine Research, HCMR), Anthony Grehan (National University of Ireland, Galway), Pilar Marin (OCEANA), Martina Milanese (GAIA), Christopher K. Pham (Instituto do Mar, Marine and Environmental Sciences Centre, University of Azores, IMARUAz, Azores), Antonio Sarà (GAIA), Katerina Sevastou (Hellenic Centre for Marine Research, HCMR), Johan van de Koppel (Royal Netherlands Institute for Sea Research, NIOZ), Teresa Amaro (ICMER, University of Porto), Laura Carugati (Università Politecnica delle Marche, UNIVPM), Inci Tuney-Kizilkaya (Ege University), Giuseppe Guarnieri (University of Salento) and Lise Tveiten (Norwegian Institute for Water Research, NIVA) for providing useful advice and comments during the focus group meeting and/or earlier parts of this work.

Saccharina latissima in Skagerrak, Norway: implications for forest recovery. J. Mar. Biol. 2011:690375. doi: 10.1155/2011/690375

Araújo, R. M., Assis, J., Aguillar, R., Airoldi, L., Bárbara, I., Bartsch, I., et al. (2016). Status, trends and drivers of kelp forests in Europe: an expert assessment. Biodiv. Conserv. 25, 1319-1348. doi: 10.1007/s10531-0161141-7

Arizmendi-Meija, R., Linares, C., Garrabou, J., Antunes, A., Ballesteros, E., Cebrián, E., et al. (2015). Combining genetic and demographic data for the conservation of a Mediterranean marine habitat-forming species. PLoS One 10:e0119585. doi: 10.1371/journal.pone.0119585

Balata, D., Piazzi, L., and Benedetti-Cecchi, L. (2007). Sediment disturbance and loss of beta diversity on subtidal rocky reefs. Ecology 88, 2455-2461. doi: 10. 1890/07-0053.1

Ballesteros, E. (1989). Production of seaweeds in Northwestern Mediterranean marine communities: its relation with environmental factors. Sci. Mar. 53, 357-364.

Ballesteros, E. (1990). Structure and dynamics of the assemblage of Cystoseira zosteroides (Turner) C. Agardh (Fucales, Phaeophyceae) in the Northwestern Mediterranean. Sci. Mar. 54, 217-229. 
Ballesteros, E. (2006). Mediterranean coralligenous assemblages: a synthesis of present knowledge. Oceanogr. Mar. Biol. Annu. Rev. 44, 123-195. doi: 10.1201/ 9781420006391.ch4

Ballesteros, E., Sala, E., Garrabou, J., and Zabala, M. (1998). Community structure and frond size distribution of a deep water stand of Cystoseira spinosa (Phaeophyta) in the Northwestern Mediterranean. Eur. J. Phycol. 33, 121-128. doi: 10.1080/09670269810001736613

Barbier, E. B., Moreno-Mateos, D., Rogers, A. D., Aronson, J., Pendleton, L., Danovaro, R., et al. (2014). Protect the deep sea. Nature 505, 475-477. doi: $10.1038 / 505475 a$

Bayraktarov, E., Saunders, M. I., Abdullah, S., Mills, M., Beher, J., Possingham, H. P., et al. (2016). The cost and feasibility of marine coastal restoration. Ecol. Appl. 26, 1055-1074. doi: 10.1890/15-1077

Bekkby, T., and Moy, F. (2011). Developing spatial models of sugar kelp (Saccharina latissima) potential distribution under natural conditions and areas of its disappearance in Skagerrak. Estuar. Coast. Shelf Sci. 95, 477-483. doi: 10.1016/j.ecss.2011.10.029

Bevilacqua, S., Guarnieri, G., Farella, G., Terlizzi, A., and Fraschetti, S. (2018). A regional assessment of the cumulative impact mapping on Mediterranean coralligenous outcrops. Sci. Rep. 8:1757. doi: 10.1038/s41598-01820297-1

Bianchi, C., Corsini-Foka, M., Morri, C., and Zenetos, A. (2014). Thirty years after - dramatic change in the coastal marine habitats of Kos Island (Greece), 1981-2013. Mediterr. Mar. Sci. 15, 482-497. doi: 10.12681/mms.678

Bodin, Ö., and Crona, B. I. (2009). The role of social networks in natural resource governance: what relational patterns make a difference? Glob. Environ. Chang. 19, 366-374. doi: 10.1016/j.gloenvcha.2009.05.002

Boström, C., Baden, S., Bockelmann, A.-C., Dromph, K., Fredriksen, S., Gustafsson, C., et al. (2014). Distribution, structure and function of Nordic eelgrass (Zostera marina) ecosystems: implications for coastal management and conservation. Aquat. Conserv. Mar. Freshw. Ecosyst. 24, 410-434. doi: 10.1002/aqc. 2424

Buhl-Mortensen, L., and Buhl-Mortensen, P. (2018). "Cold temperate coral habitats," in Corals in a Changing World, eds C. D. Beltran and E. T. Camacho (London: IntechOpen).

Buhl-Mortensen, L., Vanreusel, A., Gooday, A. J., Levin, L. A., Priede, I. G., Buhl-Mortensen, P., et al. (2010). Biological structures as a source of habitat heterogeneity and biodiversity on the deep ocean margins. Mar. Ecol. 31, 21-50. doi: $10.1111 /$ j.1439-0485.2010.00359.x

Burkholder, J. M., Tomasko, D. A., and Touchette, B. W. (2007). Seagrasses and eutrophication. J. Exp. Mar. Biol. Ecol. 350, 46-72. doi: 10.1016/j.jembe.2007. 06.024

Cancemi, G., Buia, M. C., and Mazzella, L. (2002). Structure and growth dynamics of Cymodocea nodosa meadows. Sci. Mar. 66, 365-373. doi: 10.3989/scimar. 2002.66 n 4365

Capdevila, P., Hereu, B., Riera, J. L., and Linares, C. (2016). Unravelling the natural dynamics and resilience patterns of underwater Mediterranean forests: insights from the demography of the brown alga Cystoseira zosteroides. J. Ecol. 104, 1799-1808. doi: 10.1111/1365-2745.12625

Carr, J. A., D’Odorico, P., McGlathery, K. J., and Wiberg, P. L. (2016). Spatially explicit feedbacks between seagrass meadow structure, sediment and light: habitat suitability for seagrass growth. Adv. Water Resour. 93, 315-325. doi: 10.1016/j.advwatres.2015.09.001

Carreiro-Silva, M., Andrews, A. H., Braga-Henriques, A., De Matos, V., Porteiro, F. M., and Santos, R. S. (2013). Variability in growth rates of long-lived black coral Leiopathes sp. from the Azores. Mar. Ecol. Prog. Ser. 473, 189-199. doi: $10.3354 /$ meps 10052

Cebrian, E., Linares, C., Marschal, C., and Garrabou, J. (2012). Exploring the effects of invasive algae on the persistence of gorgonian populations. Biol. Invasions 14 , 2647-2656. doi: 10.1007/s10530-012-0261-6

Cerrano, C., Danovaro, R., Gambi, C., Pusceddu, A., Riva, A., and Schiaparelli, S. (2010). Gold coral (Savalia savaglia) and gorgonian forests enhance benthic biodiversity and ecosystem functioning in the mesophotic zone. Biodivers. Conserv. 19, 153-167. doi: 10.1007/s10531-009-9712-5

Cheminée, A., Sala, E., Pastor, J., Bodilis, P., Thiriet, P., Mangialajo, L., et al. (2013). Nursery value of Cystoseira forests for Mediterranean rocky reef fishes. J. Exp. Mar. Biol. Ecol. 442, 70-79. doi: 10.1016/j.jembe.2013.02.003
Christie, H. C., Andersen, G. S., Bekkby, T., Fagerli, C. W., Gitmark, J. K., Gundersen, H., et al. (2019). Shifts between sugar kelp and turf algae in Norway: regime shifts or flips between different opportunistic seaweed species? Front. Mar. Sci. 6:72. doi: 10.3389/fmars.2019.00072

Christie, H., Norderhaug, K. M., and Fredriksen, S. (2009). Macrophytes as habitat for fauna. Mar. Ecol. Prog. Ser. 396, 221-233. doi: 10.3354/meps08351

Clark, M. R., Bowden, D. A., Rowden, A. A., and Stewart, R. (2019). Little evidence of benthic community resilience to bottom trawling on seamounts after 15 years. Front. Mar. Sci. 6:63. doi: 10.3389/fmars.2019.00063

Coma, R., Ribes, M., Zabala, M., and Gili, J. M. (1998). Growth in a modular colonial marine invertebrate. Estuar. Coast. Shelf Sci. 47, 459-470. doi: 10.1006/ ecss. 1998.0375

Costantini, F., Fauvelot, C., and Abbiati, M. (2007). Fine-scale genetic structuring in Corallium rubrum: evidence of inbreeding and limited effective larval dispersal. Mar. Ecol. Prog. Ser. 340, 109-119. doi: 10.3354/meps340109

Da Ros, Z., Antonio Dell'Anno, A., Morato, T., Sweetman, A. K., Carreiro-Silva, M., Smith, C. J., et al. (2019). The deep-sea: the new frontier for ecological restoration. Mar. Policy 108:103642. doi: 10.1016/j.marpol.2019.103642

Dailianis, T., Smith, C. J., Papadopoulou, N., Gerovasileiou, V., Sevastou, K., Bekkby, T., et al. (2018). Human activities and resultant pressures on key European marine habitats: an analysis of mapped resources. Mar. Policy 98 , 1-10. doi: 10.1016/j.marpol.2018.08.038

de Boer, W. F. (2007). Seagrass-sediment interactions, positive feedbacks and critical thresholds for occurrence: a review. Hydrobiologia 591, 5-24. doi: 10. 1007/s10750-007-0780-9

De La Fuente, G., Chiantore, M., Asnaghi, V., Kaleb, S., and Falace, A. (2019). First ex situ outplanting of the habitat-forming seaweed Cystoseira amentacea var. stricta from a restoration perspective. PeerJ 7:e7290. doi: 10.7717/peerj.7290

de los Santos, C. M., Krause-Jensen, D., Alcoverro, T., Marbà, N., Duarte, C. M., van Katwijk, M. M., et al. (2019). Recent trend reversal for declining European seagrass meadows. Nat. Commun. 10:3356. doi: 10.1038/s41467-019-11340-4

Di Camillo, C. G., and Cerrano, C. (2015). Mass mortality events in the NW Adriatic Sea: phase shift from slow- to fast-growing organisms. PLoS One 10:e0126689. doi: 10.1371/journal.pone.0126689

Duarte, C. M. (1991a). Allometric scaling of seagrass form and productivity. Mar. Ecol. Prog. Ser. 77, 289-300. doi: 10.3354/meps077289

Duarte, C. M. (1991b). Seagrass depth limits. Aquat. Bot. 40, 363-377. doi: 10.1016/ 0304-3770(91)90081-F

EC (2018). The 2018 Annual Economic Report on EU Blue Economy. European Union Technical report. Belgium: European Commision.

EEA (2015). The European Environment - State and Outlook 2015: Synthesis Report. Copenhagen: European Environment Agency.

Elliott, M., Burdon, D., Hemingway, K. L., and Apitz, S. E. (2007). Estuarine, coastal and marine ecosystem restoration: confusing management and science - A revision of concepts. Estuar. Coast. Shelf Sci. 74, 349-336. doi: 10.1016/j.ecss. 2007.05.034

Erftemeijer, P. L. A., and Lewis, R. R. R. (2006). Environmental impacts of dredging on seagrasses: a review. Mar. Pollut. Bull. 52, 1553-1572. doi: 10.1016/ j.marpolbul.2006.09.006

FAO (2009). Report of the Technical Consultation on International Guidelines for the Management of Deep-Sea Fisheries in the High Seas. Rome: FAO.

Filbee-Dexter, K., and Wernberg, T. (2018). Rise of Turfs: a new battlefront for globally declining kelp forests. Bioscience 68, 64-76. doi: 10.1093/biosci/bix147

Folke, C., Carpenter, S., Walker, B., Scheffer, M., Elmqvist, T., Gunderson, L., et al. (2004). Regime shifts, resilience, and biodiversity in ecosystem management. Annu. Rev. Ecol. Evol. Syst. 35, 557-581. doi: 10.1146/annurev.ecolsys.35. 021103.105711

Fraschetti, S., Bianchi, C. N., Terlizzi, A., Fanelli, G., Morri, C., and Boero, F. (2001). Spatial variability and human disturbance in shallow subtidal hard substrate assemblages: a regional approach. Mar. Ecol. Prog. Ser. 212, 1-12. doi: $10.3354 /$ meps212001

Garrabou, J., and Harmelin, J. G. (2002). A 20-year study on life-history traits of a harvested long-lived temperate coral in the NW Mediterranean: insights into conservation and management needs. J. Anim. Ecol. 71, 966-978. doi: $10.1046 / j .1365-2656.2002 .00661 . x$

Garrabou, J., Coma, R., Bensoussan, N., Bally, M., Chevaldonné, P., Cigliano, M., et al. (2009). Mass mortality in Northwestern Mediterranean rocky benthic 
communities: effects of the 2003 heat wave. Glob. Chang. Biol. 15, 1090-1103. doi: $10.1111 /$ j.1365-2486.2008.01823.x

Gera, A., Pagès, J., Romero, J., and Alcoverro, T. (2013). Combined effects of fragmentation and herbivory on Posidonia oceanica seagrass ecosystems. J. Ecol. 101, 1053-1061. doi: 10.1111/1365-2745.12109

Gerovasileiou, V., Smith, C. J., Sevastou, K., Papadopoulou, K.-N., Dailianis, T., Bekkby, T., et al. (2019). Habitat mapping in the European Seas - is it fit for purpose in the marine restoration agenda? Mar. Policy 106:103521. doi: 10.1016/j.marpol.2019.103521

Giakoumi, S., Sini, M., Gerovasileiou, V., Mazor, T., Beher, J., Possingham, H. P., et al. (2013). Ecoregion-based conservation planning in the Mediterranean: dealing with large-scale heterogeneity. PLoS One 8:e76449. doi: 10.1371/journal. pone.0076449

Gundersen, H., Bryan, T., Chen, W., Moy, F. E., Sandman, A. N., Sundblad, G., et al. (2016). Ecosystem Services in the Coastal Zone of the Nordic Countries. Copenhagen: Nordic Council of Ministers.

Halpern, B. S., Frazier, M., Potapenko, J., Casey, K. S., Koenig, K., Longo, C., et al. (2015). Spatial and temporal changes in cumulative human impacts on the world/'s ocean. Nat. Commun. 6:7615. doi: 10.1038/ncomms 8615

Halpern, B. S., Silliman, B. R., Olden, J. D., Bruno, J. P., and Bertness, M. D. (2007). Incorporating positive interactions in aquatic restoration and conservation. Front. Ecol. Environ. 5, 153-160. doi: 10.1890/1540-929520075[153:IPIIAR]2. $0 . \mathrm{CO} ; 2$

HELCOM (2007). HELCOM Lists of Threatened and/or Declining Species and Biotopes/Habitats in the Baltic Sea Area. Baltic Sea Environmental Proceedings No. 113. Helsinki: HELCOM.

Hemminga, M. A., and Duarte, C. M. (2000). Seagrass Ecology. Cambridge, MA: Cambridge University Press.

Hughes, T. P., Linares, C., Dakos, V., van de Leemput, I. A., and van Nes, E. H. (2013). Living dangerously on borrowed time during slow, unrecognized regime shifts. Trends Ecol. Evol. 28, 149-155. doi: 10.1016/j.tree.2012.08.022

Ingrosso, G., Abbiati, M., Badalamenti, F., Bavestrello, G., Belmonte, G., Cannas, R., et al. (2018). Mediterranean bioconstructions along the Italian Coasts. $A d v$. Mar. Biol. 79, 61-136. doi: 10.1016/bs.amb.2018.05.001

Iveša, L., Djakovac, T., and Devescovi, M. (2016). Long-term fluctuations in Cystoseira populations along the west Istrian Coast (Croatia) related to eutrophication patterns in the northern Adriatic Sea. Mar. Pollut. Bull. 106, 162-173. doi: 10.1016/j.marpolbul.2016.03.010

Jahnke, M., Christensen, A., Micu, D., Milchakova, N., Sezgin, M., Todorova, V., et al. (2016). Patterns and mechanisms of dispersal in a keystone seagrass species. Mar. Environ. Res. 117, 54-62. doi: 10.1016/j.marenvres.2016.04.004

Jahnke, M., Jonsson, P. R., Moksnes, P.-O., Loo, L.-O., Jacobi, M. N., and Olsen, J. L. (2018). Seascape genetics and biophysical connectivity modelling support conservation of the seagrass Zostera marina in the Skagerrak-Kattegat region of the eastern North Sea. Evol. Appl. 11, 645-661. doi: 10.1111/eva.12589

Källström, B., Nyqvist, A., Åberg, P., Bodin, M., and André, C. (2008). Seed rafting as a dispersal strategy for eelgrass (Zostera marina). Aquat. Bot. 88, 148-153. doi: 10.1016/j.aquabot.2007.09.005

Kilminster, K., McMahon, K., Waycott, M., Kendrick, G. A., Scanes, P., McKenzie, L., et al. (2015). Unravelling complexity in seagrass systems for management: Australia as a microcosm. Sci. Total Environ. 534, 97-109. doi: 10.1016/j. scitotenv.2015.04.061

Kovalenko, K. E., Thomaz, S. M., and Warfe, D. M. (2012). Habitat complexity: approaches and future directions. Hydrobiologia 685, 1-17. doi: 10.1007/ s10750-011-0974-z

Krause-Jensen, D., and Duarte, C. M. (2014). Expansion of vegetated coastal ecosystems in the future. Front. Mar. Sci. 1:77. doi: 10.3389/fmars.2014. 00077

Krause-Jensen, D., and Duarte, C. M. (2016). Substantial role of macroalgae in marine carbon sequestration. Nat. Geosci. 9, 737-742. doi: 10.1038/ngeo2790

Krumhansl, K., Okamoto, D. K., Rassweiler, A., Novak, M., Bolton, J. J., Cavanaugh, K. C., et al. (2016). Global patterns of kelp forest change over the past halfcentury. Proc. Natl. Acad. Sci. U.S.A. 113, 13785-13790. doi: 10.1073/pnas. 1606102113

Laborel, J. (1961). Le concretionnement algal "coralligene" et son importance geomorphologique en Mediterranee. Recl. Trav. Stat. Mar. d'End. 23, 37-60.

Leclerc, J.-C., Riera, P., Leroux, C., Lévêque, L., Laurans, M., Schall, G., et al. (2013). Trophic significance of kelps in kelp communities in Brittany (France) inferred from isotopic comparisons. Mar. Biol. 160, 3249-3258. doi: 10.1007/s00227013-2306-5

Ledoux, J. B., Garrabou, J., Bianchimani, O., Drap, P., Féral, J. P., and Aurelle, D. (2010). Fine-scale genetic structure and inferences on population biology in the threatened Mediterranean red coral, Corallium rubrum. Mol. Ecol. 19, 4204-4216. doi: 10.1111/j.1365-294X.2010.04814.x

Linares, C., Coma, R., and Zabala, M. (2008). Restoration of threatened gorgonian populations: an experimental and modeling approach. Biol. Conserv. 141, 427-443. doi: 10.1016/j.biocon.2007.10.012

Linares, C., Doak, D., Coma, R., Diaz, D., and Zabala, M. (2007). Life history and viability of a long-lived marine invertebrate: the octocoral Paramuricea clavata. Ecology 88, 918-928. doi: 10.1890/05-1931

Ling, S. D., Scheibling, R. E., Rassweiler, A., Johnson, C. J., Shears, N., Connell, S. D., et al. (2015). Global regime shift dynamics of catastrophic sea urchin overgrazing. Philos. Trans. R. Soc. B 370, 20130269. doi: 10.1098/rstb.2013. 0269

Mangialajo, L., Chiantore, M., Susini, M. L., Meinesz, A., Cattaneo-Vietti, R., and Thibaut, T. (2012). Zonation patterns and interspecific relationships of fucoids in microtidal environments. J. Exp. Mar. Biol. Ecol. 412, 72-80. doi: 10.1016/j. jembe.2011.10.031

Maxwell, P. S., Eklöf, J. S., van Katwijk, M. M., O’Brien, K. R., de la Torre-Castro, M., Boström, C., et al. (2016). The fundamental role of ecological feedback mechanisms for the adaptive management of seagrass ecosystems - a review. Biol. Rev. 92, 1521-1538. doi: 10.1111/brv.12294

McDonald, T., Gann, G. D., Jonson, J., and Dixon, K. W. (2016). International Standards for the Practice of Ecological Restoration - Including Principles and Key Concepts. Washington DC: Society for Ecological Restoration.

McMahon, K., van Dijk, K., Ruiz-Montoya, L., Kendrick, G. A., Krauss, S. L., Waycott, M., et al. (2014). The movement ecology of seagrasses. Proc. R. Soc. B 281:20140878. doi: 10.1098/rspb.2014.0878

Moksnes, P.-O., Eriander, L., Infantes, E., and Holmer, M. (2018). Local regime shifts prevent natural recovery and restoration of lost eelgrass beds along the Swedish west coast. Estuar. Coasts 41, 1712-1731. doi: 10.1007/s12237-0180382-y

Moksnes, P.-O., Gullström, M., Tryman, K., and Baden, S. (2008). Trophic cascades in a temperate seagrass community. Oikos 117, 763-777. doi: 10.1111/j.00301299.2008.16521.x

Montero-Serra, I., Garrabou, J., Doak, D., Hereu, B., Ledoux, J. B., and Linares, C. (2018a). Accounting for life-history strategies and timescales in marine restoration. Conserv. Lett. 11:e12341. doi: 10.1111/conl. 12341

Montero-Serra, I., Linares, C., Doak, K., Ledoux, J. B., and Garrabou, J. (2018b). Strong linkages between depth, longevity and demographic stability across marine sessile species. Proc. R. Soc. B Biol. Sci. 285:20172688. doi: 10.1098/rspb. 2017.2688

Moy, F., and Christie, H. (2012). Large-scale shift from sugar kelp (Saccharina latissima) to ephemeral algae along the south and west coast of Norway. Mar. Biol. Res. 8, 309-321. doi: 10.1080/17451000.2011.637561

Olesen, B., and Sand-Jensen, K. (1993). Seasonal acclimatization of eelgrass Zostera marina growth to light. Mar. Ecol. Prog. Ser. 94, 91-99. doi: 10.3354/ meps094091

Olsen, J. L., Stam, W. T., and Coyer, J. A. (2004). Population differentiation and post-ice age recolonization of the North Atlantic by the seagrass Zostera marina L. Mol. Ecol. 13, 1923-1941. doi: 10.1111/j.1365-294x.2004.02205.x

Orth, R. J., Carruthers, T. J., Dennison, W. C., Duarte, C. M., Fourqurean, J. W., Heck, K. L., et al. (2006). A global crisis for seagrass ecosystems. Bioscience 56, 987-996. doi: 10.1016/j.tree.2019.04.004

Orth, R. J., Luckenbach, M., and Moore, K. A. (1994). Seed dispersal in a marine macrophyte: implications for colonization and restoration. Ecology 75, 19271939. doi: $10.2307 / 1941597$

OSPAR (2008). Case Reports for the OSPAR List of Threatened and/or Declining Species and Habitats. London: OSPAR.

Pascual, M., Rives, B., Schunter, C., and Macpherson, E. (2017). Impact of life history traits on gene flow: a multispecies systematic review across oceanographic barriers in the Mediterranean Sea. PLoS One 12:e0176419. doi: 10.1371/journal.pone.0176419

Pauly, D. (1995). Anecdotes and the shifting baseline syndrome of fisheries. Trends Ecol. Evol. 10:430. doi: 10.1016/s0169-5347(00)89171-5 
Perkol-Finkel, S., and Airoldi, L. (2010). Loss and recovery potential of marine habitats: an experimental study of factors maintaining resilience in subtidal algal forests at the Adriatic Sea. PLoS One 5:e10791. doi: 10.1371/journal.pone. 0010791

Piazzi, L., Gennaro, P., and Balata, D. (2012). Threats to macroalgal coralligenous assemblages in the Mediterranean Sea. Mar. Pollut. Bull. 64, 2623-2629. doi: 10.1016/j.marpolbul.2012.07.027

Pinnegar, J. K., Polunin, N. V. C., Francour, P., Badalamenti, F., Chemello, R., Harmelin-Vivien, M. L., et al. (2000). Trophic cascades in benthic marine ecosystems: lessons for fisheries and protected-area management. Environ. Conserv. 27, 179-200. doi: 10.1017/S0376892900000205

Ponti, M., Perlini, R. A., Ventra, V., Grech, D., Abbiati, M., and Cerrano, C. (2014). Ecological shifts in Mediterranean coralligenous assemblages related to gorgonian forest loss. PLoS One 9:e102782. doi: 10.1371/journal.pone.0102782

Possingham, H. P., Bode, M., and Klein, C. J. (2015). Optimal Conservation Outcomes Require Both Restoration and Protection. PLoS Biol. 13:e1002052. doi: 10.1371/journal.pbio.1002052

Ragnarsson, S. Á, Burgos, J. M., Kutti, T., van den Beld, I., Egilsdóttir, H., ArnaudHaond, S., et al. (2017). "The impact of anthropogenic activity on coldwater corals," in Marine Animal Forests, eds S. Rossi, L. Bramanti, A. Gori, and C. Orejas (Cham: Springer), 1-35. doi: 10.1007/978-3-319-17001-5_27-1

Ramirez-Llodra, E., Tyler, P. A., Baker, M. C., Bergstad, O. A., Clark, M. R., Escobar, E., et al. (2011). Man and the last great wilderness: human impact on the Deep Sea. PLoS One 6:e22588. doi: 10.1371/journal.pone.0022588

Reed, D. C., Amsler, C. D., and Ebling, A. W. (1992). Dispersal in kelps: factors affecting spore swimming and compentency. Ecology 73, 1577-1585. doi: 10. 2307/1940011

Reed, D. C., Anderson, T. W., Ebeling, A. W., and Anghera, M. (1997). The role of reproductive synchrony in the colonization potential of kelp. Ecology 78, 2443-2457. doi: 10.1890/0012-9658(1997)078\%5B2443:trorsi\%5D2.0.co;2

Reusch, T. B. H., Ehlers, A., Haemmerli, A., and Worm, B. (2005). Ecosystem recovery after climatic extremes enhanced by genotypic diversity. Proc. Natl. Acad. Sci. U.S.A. 102, 2826-2831. doi: 10.1073/pnas.0500008102

Roberts, J. M., Wheeler, A., Freiwald, A., and Cairns, S. D. (2009). Cold-Water Corals: The Biology and Geology of Deep-Sea Coral Habitats. Cambridge, MA: Cambridge University Press.

SER (2004). Society for Ecological Restoration International Science \& Policy Working Group. 2004. The SER International Primer on Ecological Restoration. Washington, DC: Society for Ecological Restoration International.

Silliman, B. R., Schrack, E., He, Q., Cope, R., Santoni, A., van der Heide, T., et al. (2015). Facilitation shifts paradigms and can amplify coastal restoration efforts. Proc. Natl. Acad. Sci. U.S.A. 112, 14295-14300. doi: 10.1073/pnas.1515297112

Smale, D. A., Burrows, M. T., Moore, P., O'Connor, N., and Hawkins, S. J. (2013). Threats and knowledge gaps for ecosystem services provided by kelp forests: a northeast Atlantic perspective. Ecol. Evol. 3, 4016-4038. doi: 10.1002/ ece 3.774

Steneck, R. S., Graham, M. H., Bourque, B. J., Bruce, J., Corbett, D., Erlandson, J. M., et al. (2002). Kelp forest ecosystems: biodiversity, stability, resilience and future. Environ. Conserv. 29, 436-459. doi: 10.1017/S0376892902000322

Suykerbuyk, W., Govers, L. L., Bouma, T. J., Giesen, W. B. J. T., de Jong, D. J., van de Voort, R., et al. (2016). Unpredictability in seagrass restoration: analysing the role of positive feedback and environmental stress on Zostera noltii transplants. J. Appl. Ecol. 53, 774-784. doi: 10.1111/1365-2664.12614

Teixidó, N., Garrabou, J., and Harmelin, J.-G. (2011). Low dynamics, high longevity and persistence of sessile structural species dwelling on Mediterranean coralligenous outcrops. PLoS One 6:e23744. doi: 10.1371/journal.pone.002 3744

Thibaut, T., Blanfuné, A., Boudouresque, C. F., and Verlaque, M. (2015). Decline and local extinction of Fucales in the French Riviera: the harbinger of future extinctions? Mediterr. Mar. Sci. 16, 206-224. doi: 10.12681/mms.1032

Thibaut, T., Bottin, L., Aurelle, D., Boudouresque, C., Blanfune, A., Verlaque, M., et al. (2016). Connectivity of populations of the seaweed Cystoseira amentacea within the Bay of Marseille (Mediterranean Sea): genetic structure and hydrodynamic connections. Cryptogam. Algol. 37, 233-255. doi: 10.7872/ crya/v37.iss4.2016.233

van Dover, C. L., Aronson, J., Pendleton, L., Smith, S., Arnaud-Haond, S., MorenoMateos, D., et al. (2014). Ecological restoration in the deep sea: desiderata. Mar. Policy 44, 98-106.

van Katwijk, M. M., Thorhaug, A., Marbà, N., Orth, R. J., Duarte, C. M., Kendrick G. A., et al. (2016). Global analysis of seagrass restoration: the importance of large-scale planting. J. Appl. Ecol. 53, 567-578. doi: 10.1111/1365-2664.12562

Verdura, J., Linares, L., Ballesteros, E., Coma, R., Uriz, M. J., Bensoussan, N., et al. (2019). Biodiversity loss in a Mediterranean ecosystem due to an extreme warming event unveil the role of an engineering gorgonian species. Sci. Rep. 9:5911. doi: 10.1038/s41598-019-41929-0

Verdura, J., Vergés, A., Santamaria, J., De Caralt, S., Ballesteros, E., and Cebrian, E. (2018). Drastic effects of climate change on Mediterranean marine forest. PeerJ 6:e26804v2.

Watling, L., France, S. C., Pante, E., and Simpson, A. (2011). Biology of deepwater octocorals. Adv. Mar. Biol. 60, 41-122. doi: 10.1016/B978-0-12-3855299.00002-0

Waycott, M., Duarte, C. M., Carruthers, T. J., Orth, R. J., Dennison, W. C., Olyarnik, S., et al. (2009). Accelerating loss of seagrasses across the globe threatens coastal ecosystems. Proc. Natl. Acad. Sci. U.S.A. 106, 12377-12381. doi: 10.1073/pnas.0905620106

Worm, B., Barbier, E. B., Beaumont, N., Duffy, J. E., Folke, C., Halpern, B. S., et al. (2006). Impacts of biodiversity loss on ocean ecosystem services. Science 314, 787-790. doi: 10.1126/science.1132294

Conflict of Interest: The authors declare that the research was conducted in the absence of any commercial or financial relationships that could be construed as a potential conflict of interest.

Copyright (C) 2020 Bekkby, Papadopoulou, Fiorentino, McOwen, Rinde, Boström, Carreiro-Silva, Linares, Andersen, Bengil, Bilan, Cebrian, Cerrano, Danovaro, Fagerl, Fraschetti, Gagnon, Gambi, Gundersen, Kipson, Kotta, Morato, Ojaveer, Ramirez-Llodra and Smith. This is an open-access article distributed under the terms of the Creative Commons Attribution License (CC BY). The use, distribution or reproduction in other forums is permitted, provided the original author(s) and the copyright owner(s) are credited and that the original publication in this journal is cited, in accordance with accepted academic practice. No use, distribution or reproduction is permitted which does not comply with these terms. 